Brit. Heart F., 1967, 29, 333.

\title{
Incidence of Atherosclerotic Lesions at Madras, South India
}

\author{
R. SUBRAMANIAM AND ABRAHAM C. KULANGARA*
}

From the Department of Medicine, Madras Medical College, and the Government General Hospital, Madras 3, India

The incidence of atherosclerotic lesions in an urban population in South India has not been examined quantitatively. A study of the material from the mortuary of the Government General Hospital in Madras city was therefore started in 1963 and a preliminary report on about 260 cases was made in 1964 (Kulangara and Subramaniam, 1964). However, that sample did not include female specimens in the first and ninth decades and lacked adequate numbers of both sexes in other decades as well. The work was continued in order to extend the age range and to increase the number of cases in the separate decades. The results from about 500 cases are reported here since they provide a more accurate estimate of the frequency of diseased arteries and the extent and severity of lesions.

\section{Material aNd MethodS}

The heart and the entire aorta with about $8 \mathrm{~cm}$. of the iliac (common and external) and 10-12 cm. of the innominate and common carotid arteries attached to it were obtained from all necropsies, except when the bodies were decomposed. For purposes of this study, the coronary arteries are considered as one blood vessel, and estimates of the two iliac arteries are also combined as for one vessel. The arteries of the neck are designated hereafter as the innominate on the right side and the common carotid on the left side.

The coronary arteries and the aorta and its branches were cut open along their length and their inner surfaces were wiped clean. Lesions were usually appraised by sight, but stained sections were prepared in order to differentiate fatty streaks from fibrous plaques. The proportion of the intimal surface occupied by each grade of lesion was estimated and the atherosclerotic profile was recorded for each artery according to the methcd devised by Gore and Tejada (1957). Subsequently, atherosclerotic indices were calculated from these profile records.

Received October 27, 1965.

* Present address: Institute of Animal Genetics, West Mains Road, Edinburgh 9.

z

\section{RESULTS}

The sample consists of 492 hearts and 502 aortas, obtained from persons ranging in age from $2 \frac{1}{2}$ to 94 years. The iliac, innominate, and common carotid arteries of 3,7, and 3 per cent of the aortas were not available for examination. About 65 per cent of the sample were men.

Frequency of Diseased Arteries. Arteries with an index value above 0.033 are considered to show significant atherosclerosis, and the percentage of such arteries in each decade and sex is given in Table $I$.

The aorta is the most frequently diseased artery; at least two-thirds of them are affected by the second decade and after the fourth decade no aorta is free from lesions. The innominate and common carotid arteries are affected less frequently, both of them showing about the same percentages throughout the decades. The iliacs seem to be the next commonly affected, though the percentages of diseased coronary arteries are almost the same. About 8 per cent of the coronary arteries examined in the second decade have an index above 0.033 ; the percentages are higher in the later decades, but even in the sixth and seventh decades there are a few which are free from lesions.

The frequencies for the aorta and innominate arteries in both sexes are similar throughout the decades. The coronary and iliac arteries, however, show a significant $(p<0.05)$ difference between the sexes in the third decade, men showing a higher percentage of diseased arteries than women. In addition, when the percentages in all the decades are compared, the coronary, iliac, and common carotid arteries of men are $(p<0.01)$ more frequently affected than those of women. Thus, men are more likely than women to have more diseased coronary, iliac, and common carotid arteries, though the difference is large in only one decade and for two of the arteries. 
TABLE I

NUMBER OF CORONARY ARTERIES AND AORTAS EXAMINED WITH PERCENTAGE OF DISEASED ARTERIES*, IN RELATION TO AGE AND SEX

\begin{tabular}{|c|c|c|c|c|c|c|c|c|c|c|c|c|c|c|}
\hline \multirow{3}{*}{$\begin{array}{c}\text { Age } \\
\text { decade }\end{array}$} & \multicolumn{7}{|c|}{ Male } & \multicolumn{7}{|c|}{ Female } \\
\hline & \multicolumn{2}{|c|}{$\begin{array}{c}\text { Coronary } \\
\text { arteries }\end{array}$} & \multicolumn{2}{|c|}{ Aorta } & \multirow{2}{*}{$\begin{array}{c}\text { Iliac } \\
\%\end{array}$} & \multirow{2}{*}{$\begin{array}{c}\text { Innominate } \\
(\%)\end{array}$} & \multirow{2}{*}{$\begin{array}{c}\text { Common } \\
\text { carotid } \\
(\%)\end{array}$} & \multicolumn{2}{|c|}{$\begin{array}{c}\text { Coronary } \\
\text { arteries }\end{array}$} & \multicolumn{2}{|c|}{ Aorta } & \multirow{2}{*}{$\begin{array}{r}\text { Iliac } \\
(\%)\end{array}$} & \multirow{2}{*}{$\begin{array}{c}\text { Innominate } \\
(\%)\end{array}$} & \multirow{2}{*}{$\begin{array}{c}\begin{array}{c}\text { Common } \\
\text { carotid } \\
(\%)\end{array} \\
\end{array}$} \\
\hline & No. & $\%$ & No. & $\%$ & & & & No. & $\%$ & No. & $\%$ & & & \\
\hline $\begin{array}{r}1 \\
2 \\
3 \\
4 \\
5 \\
6 \\
7 \\
8 \\
9 \\
10\end{array}$ & $\begin{array}{r}8 \\
45 \\
110 \\
64 \\
51 \\
25 \\
11 \\
3\end{array}$ & $\begin{array}{r}0 \\
7 \\
30 \\
72 \\
88 \\
100 \\
91 \\
100\end{array}$ & $\begin{array}{r}8 \\
46 \\
114 \\
68 \\
50 \\
28 \\
11 \\
3\end{array}$ & $\begin{array}{r}0 \\
67 \\
88 \\
93 \\
100 \\
100 \\
100 \\
100\end{array}$ & $\begin{array}{r}0 \\
13 \\
38 \\
67 \\
94 \\
96 \\
100 \\
100\end{array}$ & $\begin{array}{r}0 \\
28 \\
50 \\
75 \\
90 \\
100 \\
100 \\
100\end{array}$ & $\begin{array}{r}0 \\
38 \\
51 \\
78 \\
92 \\
96 \\
100 \\
100\end{array}$ & $\begin{array}{r}11 \\
53 \\
66 \\
23 \\
16 \\
9 \\
5 \\
0 \\
1 \\
1\end{array}$ & $\begin{array}{r}0 \\
8 \\
17 \\
70 \\
69 \\
89 \\
100 \\
100 \\
0\end{array}$ & $\begin{array}{r}11 \\
56 \\
62 \\
22 \\
17 \\
9 \\
5 \\
0 \\
1 \\
1\end{array}$ & $\begin{array}{r}0 \\
79 \\
82 \\
95 \\
100 \\
100 \\
100 \\
100 \\
100\end{array}$ & $\begin{array}{r}0 \\
9 \\
17 \\
71 \\
94 \\
88 \\
100 \\
100 \\
100\end{array}$ & $\begin{array}{r}0 \\
34 \\
37 \\
76 \\
93 \\
86 \\
100 \\
100 \\
100\end{array}$ & $\begin{array}{r}28 \\
36 \\
68 \\
88 \\
100 \\
100 \\
100\end{array}$ \\
\hline Totals & 317 & & 328 & & & & & 175 & & 174 & & & & \\
\hline
\end{tabular}

* The number of arteries with an atherosclerotic index above 0.033 expressed as a percentage of the number of arteries examined.

Extent and Severity of Lesions. The atherosclerotic index is a combined measure of the extent and severity of lesions. The mean and range of indices of the various arteries are given in Table II.

The arteries examined here may be arranged in a series, based on curves fitted to the mean indices at various decades. The aorta of both sexes is the most heavily diseased, followed by the male coronary and iliac arteries, then the female iliac arteries, then the innominate and common carotid arteries of both sexes, and finally the female coronary arteries. The proportion of arteries that show a high index in the third, fourth, and fifth decades emphasizes the considerable difference between the aorta and female coronary arteries. Thus, 6 per cent of the aortas in the third, 33 per cent in the fourth, and 85 per cent in the fifth decades, and none of the female coronary arteries in the third, and 13 per cent of them in the fourth and fifth decades, show indices of 10 or above.

TABLE II

MEAN ATHEROSCLEROTIC INDICES (VALUES IN PARENTHESES ARE RANGES)

\begin{tabular}{|c|c|c|c|c|c|c|c|c|c|c|}
\hline \multirow[b]{2}{*}{$\begin{array}{l}\text { Age } \\
\text { decade- }\end{array}$} & \multicolumn{5}{|c|}{ Male } & \multicolumn{5}{|c|}{ Female } \\
\hline & $\begin{array}{c}\text { Coronary } \\
\text { arteries }\end{array}$ & Aorta & Iliacs & $\begin{array}{l}\text { Innom- } \\
\text { inate }\end{array}$ & $\begin{array}{c}\text { Common } \\
\text { carotid }\end{array}$ & $\begin{array}{c}\text { Coronary } \\
\text { arteries }\end{array}$ & Aorta & Iliacs & $\underset{\text { inate }}{\text { Innom- }}$ & $\begin{array}{c}\text { Common } \\
\text { carotid }\end{array}$ \\
\hline 1 & $\underline{0}$ & $\begin{array}{c}0.017 \\
(0-0.033)\end{array}$ & $\begin{array}{c}0.004 \\
(0-0.033)\end{array}$ & $\begin{array}{c}0.004 \\
(0-0.033)\end{array}$ & $\begin{array}{c}0.008 \\
(0-0.033)\end{array}$ & $\underline{0}$ & $\underline{0}$ & $\underline{0}$ & $\underline{0}$ & \\
\hline 2 & $(0-0.973)$ & $\begin{array}{r}0.468 \\
(0-4.6)\end{array}$ & $\begin{array}{c}0.046 \\
(0-0.533)\end{array}$ & $\begin{array}{c}0 \cdot 162 \\
(0-1 \cdot 83)\end{array}$ & $\begin{array}{c}0.201 \\
(0-2 \cdot 93)\end{array}$ & $\begin{array}{c}0.027 \\
(0-0.33)\end{array}$ & $\begin{array}{c}0.446 \\
(0.033-4 \cdot 37)\end{array}$ & $\begin{array}{c}0.085 \\
(0-3.33)\end{array}$ & $\begin{array}{c}0.093 \\
(0-0.533)\end{array}$ & $\begin{array}{c}0 \cdot 117 \\
(0-1 \cdot 33)\end{array}$ \\
\hline 3 & $\begin{array}{r}0.412 \\
(0-19)\end{array}$ & $\begin{array}{c}2 \cdot 18 \\
(0-28)\end{array}$ & $\begin{array}{c}0.855 \\
(0-29 \cdot 3)\end{array}$ & $\begin{array}{r}0.737 \\
(0-10)\end{array}$ & $\begin{array}{r}0.658 \\
(0-10)\end{array}$ & $\begin{array}{c}0 \cdot 164 \\
(0-3 \cdot 33)\end{array}$ & $\begin{array}{c}1.3 \\
(0.033-10)\end{array}$ & $\begin{array}{c}0.101 \\
(0-1 \cdot 33)\end{array}$ & $\begin{array}{c}0.213 \\
(0-1 \cdot 83)\end{array}$ & $\begin{array}{c}0.181 \\
(0-2.45)\end{array}$ \\
\hline 4 & $\begin{array}{c}1.99 \\
(0-19)\end{array}$ & $\begin{array}{c}6.56 \\
(0.033-37)\end{array}$ & $\begin{array}{c}3 \cdot 83 \\
(0-33 \cdot 3)\end{array}$ & $\begin{array}{c}2 \cdot 11 \\
(0-10)\end{array}$ & $\begin{array}{c}2 \cdot 46 \\
(0-10 \cdot 9)\end{array}$ & $\begin{array}{l}1 \cdot 89 \\
(0-19)\end{array}$ & $\begin{array}{c}5 \cdot 73 \\
(0-46)\end{array}$ & $\begin{array}{c}3 \cdot 82 \\
(0-46)\end{array}$ & $\begin{array}{c}2.92 \\
(0-10)\end{array}$ & $\begin{array}{c}2 \cdot 23 \\
(0-10)\end{array}$ \\
\hline 5 & $\begin{array}{l}17 \cdot 5 \\
(0-100)\end{array}$ & $\begin{array}{c}24 \cdot 9 \\
(0 \cdot 33-100)\end{array}$ & $\begin{array}{l}19 \cdot 0 \\
(0-100)\end{array}$ & $\begin{array}{c}7 \cdot 26 \\
(0-51 \cdot 4)\end{array}$ & $\begin{array}{c}6 \cdot 39 \\
(0-22 \cdot 6)\end{array}$ & $\begin{array}{c}3.44 \\
(0.033-19 \cdot 7)\end{array}$ & $(0 \cdot 533-64)$ & $\begin{array}{c}9 \cdot 4 \\
(0-46)\end{array}$ & $\begin{array}{c}5 \cdot 37 \\
(0.033-18 \cdot 1)\end{array}$ & $\begin{array}{c}4 \cdot 45 \\
(0-10)\end{array}$ \\
\hline 6 & $\begin{array}{c}14 \cdot 3 \\
(0 \cdot 13-100)\end{array}$ & $\begin{array}{c}21 \cdot 5 \\
(1 \cdot 21-55)\end{array}$ & $\begin{array}{l}21 \cdot 2 \\
(0-91)\end{array}$ & $\begin{array}{c}7 \cdot 16 \\
(0.093-19)\end{array}$ & $\begin{array}{c}6 \cdot 61 \\
(0-10)\end{array}$ & $\begin{array}{c}7 \cdot 14 \\
(0-19 \cdot 7)\end{array}$ & $\begin{array}{c}27 \cdot 3 \\
(9 \cdot 1-80 \cdot 2)\end{array}$ & $\begin{array}{l}12 \cdot 4 \\
(0 \cdot 033-28)\end{array}$ & $\begin{array}{c}6.04 \\
(0.033-10)\end{array}$ & $\begin{array}{c}6 \cdot 36 \\
(1 \cdot 33-10)\end{array}$ \\
\hline 7 & $\begin{array}{c}19 \cdot 1 \\
(0 \cdot 033-73)\end{array}$ & $\begin{array}{l}25 \cdot 5 \\
(10-46)\end{array}$ & $\begin{array}{c}12 \cdot 3 \\
(3 \cdot 33-28)\end{array}$ & $\begin{array}{c}7 \cdot 26 \\
(0.533-10)\end{array}$ & $\left(\begin{array}{c}7 \cdot 84 \\
(1 \cdot 01-10)\end{array}\right.$ & $\begin{array}{c}12 \cdot 3 \\
(3 \cdot 33-28)\end{array}$ & $\begin{array}{l}27 \cdot 5 \\
(7 \cdot 3-46)\end{array}$ & $\begin{array}{l}13 \cdot 7 \\
(1 \cdot 33-28)\end{array}$ & $\begin{array}{l}11 \cdot 6 \\
(9 \cdot 1-19)\end{array}$ & $\begin{array}{c}9 \cdot 82 \\
(9 \cdot 1-10)\end{array}$ \\
\hline 8 & $\begin{array}{l}34 \cdot 0 \\
(10-82)\end{array}$ & $\begin{array}{l}28 \cdot 0 \\
(10-55)\end{array}$ & $\begin{array}{l}22 \cdot 0 \\
(10-37)\end{array}$ & $\begin{array}{l}14 \cdot 5 \\
(10-19)\end{array}$ & $\begin{array}{c}9 \cdot 7 \\
(9 \cdot 1-10)\end{array}$ & & & & & \\
\hline 9 & & & & & & $9 \cdot 73$ & 46.0 & 5.33 & $10 \cdot 0$ & $10 \cdot 0$ \\
\hline 10 & & & & & & $\underline{0}$ & $26 \cdot 1$ & $28 \cdot 0$ & 28.0 & \\
\hline
\end{tabular}

The numbers of arteries examined in the various classes are given in Table $I$. 
The mean index of the aorta increases gradually during the first three decades, very rapidly in the next two decades, and at a slower rate in the remaining decades. The rate of increase of the mean index is more uniform in the other arteries.

Comparison of indices between men and women reveals a large difference only in the coronary arteries. The mean indices in women lag almost two decades behind those in men. The differences are significantly large in the third and fifth decades; they are smaller in other decades, probably due to the variances in men being several times those in women.

\section{DisCUSSION}

The ratio of diseased to healthy arteries is at least as important information as the extent and severity of lesions in the affected arteries. There are surprisingly few reports on the percentage of diseased arteries in each decade and sex and none of the studies from India have looked at this aspect. We reported earlier that there were no significant differences between the sexes in the percentages of diseased arteries (Kulangara and Subramaniam, 1964). The larger sample examined here shows a higher incidence of diseased coronary, iliac, and common carotid arteries in men. It may be pointed out that not many more men show diseased coronary arteries than women, except in the third decade (Table I), but men with coronary lesions in most decades are much more severely affected than women (Table II), making them more liable to clinical coronary heart disease.

Quantitative data on the extent and severity of lesions at Agra (Mathur, Patney, and Kumar, 1961) and Vellore (Gore et al., 1960; Samuel, Gault, and Sudarsanam, 1962) in India are available. Both Agra and Vellore differ very much from Madras, the former in the food habits of the people and the latter in the rural nature of the population. The majority of cases examined here are from necropsies of people who were destitute or of a low socio-economic level; this is probably true of the sample from Vellore (Samuel et al., 1962) also. Therefore, it is significant that a much more severe involvement of the aorta and coronary arteries is evident from the present data. The mean aortic indices of the Agra and Vellore samples are in agreement, whereas indices obtained here are four to five times those values in the second, third, and fourth decades and two to three times in later decades.

Hill et al. (1961) observed that atherosclerosis in the North London area was very similar to that recorded at New Orleans (Tejada and Gore, 1957).
The high mean indices obtained here indicate the severity to be similar to what those studies have reported from England and the United States. Our data are also in disagreement with the view that aortic and coronary atherosclerosis are relatively mild in India (Gore et al., 1960). Judged by the mean indices at various decades, aortic lesions at Madras are almost as severe as in the United States. It may be pointed out that Gore et al (1960) found that aortic lesions in Jamaica and Japan, where the diet is rich in carbohydrates, as it is in Madras, approached the extent and severity of that seen in the United States.

As already mentioned, a large difference between the coronary mean indices for each sex is evident from these data. The mean coronary indices in men here are much higher than those reported from Agra and similar to values obtained in the United States. The considerably lower figures recorded here for the female coronary arteries are similar to values for the aorta from Agra and Vellore. Separate data for the sexes are not available from Vellore, and the male and female indices for the coronary arteries from Agra do not seem to differ significantly. Others have reported the absence of any sex difference (Roberts, Wilkins, and Moses, 1959b) and the presence of a sex difference in some decades (Roberts, Moses, and Wilkins, 1959a) and in all decades (Groom et al., 1959). In the present sample, the frequency of coronary atherosclerosis and even more so the extent and severity of coronary lesions are greater in men.

\section{SUMMARY}

A sample of 492 hearts and 502 aortas, from people ranging in age from $2 \frac{1}{2}$ to 94 years, has been examined for atherosclerotic lesions. The atherosclerotic index for the coronary arteries, the aorta, and portions of the iliac, innominate, and common carotid arteries obtained along with the aorta, has been calculated. The data have been analysed according to sex and age-groups.

The arteries may be arranged in the following descending series, according to the percentages that are diseased in the various decades: the aorta, the innominate and common carotid arteries, and the iliac and coronary arteries. The male coronary, iliac, and common carotid arteries are more frequently affected, particularly in the third decade.

The mean atherosclerotic indices in the various decades place the arteries in the following descending series, beginning with the one most heavily diseased: aorta of both sexes, male coronary and iliac arteries, female iliac arteries, innominate 
and common carotid arteries of both sexes, the female coronary arteries. Consistently large differences have been observed between the mean indices of the male and female coronary arteries; the difference is considered to be significant.

The mean indices of the aorta of both sexes and the male coronary arteries indicate a much greater severity of the disease at Madras than so far reported from any other place in India. The disease appears to be as severe here as it is in England and the United States.

We are grateful to Professor C. B. Gopalakrishna and to other staff members of the Department of Forensic Medicine for their co-operation in placing the necropsy material at our disposal. The study was assisted by a grant from the Madras State Research Committee.

\section{REFERENCES}

Gore, I., Robertson, W. B., Hirst, A. E., Hadley, G. G., and Koseki, Y. (1960). Geographic differences in the severity of aortic and coronary atherosclerosis: The United States, Jamaica, W.I., South India, and Japan. Amer. F. Path., 36, 559.

- and Tejada, C. (1957). The quantitative appraisal of atherosclerosis. Amer. F. Path., 33, 875.
Groom, D., McKee, E. E., Webb, C., Grant, F. W., Pean, V., Hudicourt, E., and Dallemand, J. (1959). Coronary and aortic atherosclerosis in the Negroes of Haiti and the United States. Ann. intern. Med., 51, 270.

Hill, K. R., Camps, F. E., Rigg, K., and McKinney, B. E. G. (1961). Atherosclerosis: results of a pilot survey in a North London area. Brit. med. F., 1, 1190.

Kulangara, A. C., and Subramaniam, R. (1964). Autopsy study of atherosclerosis at Madras, South India. Circulation, 29, 546.

Mathur, K. S., Patney, N. L., and Kumar, V. (1961). Atherosclerosis in India: an autopsy study of the aorta and the coronary, cerebral, renal, and pulmonary arteries. Circulation, 24, 68.

Roberts, J. C., Jr., Moses, C., and Wilkins, R. H. (1959a). Autopsy studies in atherosclerosis. I. Distribution and severity of atherosclerosis in patients dying without morphologic evidence of atherosclerotic catastrophe. Circulation, 20, 511.

—, Wilkins, R. H., and Moses, C. (1959b). Autopsy studies in atherosclerosis. II. Distribution and severity of atherosclerosis in patients dying with morphologic evidence of atherosclerotic catastrophe. Circulation, 20, 520.

Samuel, I., Gault, E. W., and Sudarsanam, D. (1962). A post-mortem study of the incidence of atherosclerosis in the aorta and the coronary vessels. In Seminar on Atherosclerosis and Ischremic Heart Disease, p. 105. Indian Council of Medical Research, New Delhi.

Tejada, C., and Gore, I. (1957). Comparison of atherosclerosis in Guatemala City and New Orleans. Amer. $\mathcal{F}$. Path., 33, 887. 